\title{
名古屋大学における生命倫理審查委員会の 事前審查に関する状況調查
}

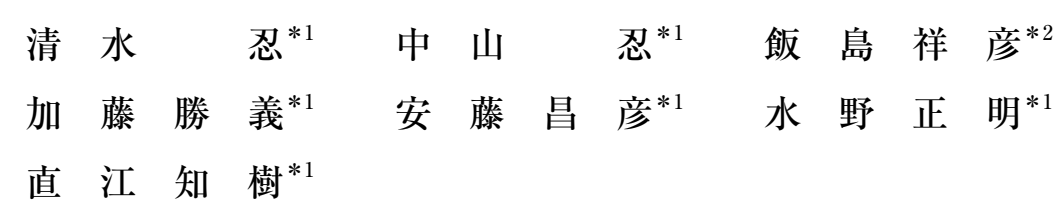

\section{Nagoya University Ethics Committee's Preliminary Review Process: A Descriptive Study}

\author{
Shinobu SHIMIZU*1, Shinobu NAKAYAMA ${ }^{* 1}$, Yoshihiko IIJIMA*2, Katsuyoshi KATO*1, \\ Masahiko ANDO*1, Masaaki MIZUNO*1 and Tomoki NAOE*1 \\ ${ }^{* 1}$ Center for Advanced Medicine and Clinical Research, Nagoya University Hospital, Aichi, Japan \\ ${ }^{* 2}$ Department of Ethics Review Committee, Nagoya University Graduate School of Medicine, Aichi, Japan
}

\begin{abstract}
The Nagoya University Ethics Committee (NUEC) is responsible for reviewing the appropriateness of research protocols from ethical and scientific points of view. In March 2011, to support and enrich the review process, a system of preliminary reviews was implemented. We analyzed all of the research protocol applications that were submitted to the NUEC between April 2011 and March 2012 (FY2011) and for which a result notification was issued and compared the total review times for FY2009 (between April 2009 and March 2010) and FY2011. In FY2011 and FY2009, 259 and 242 applications, respectively, were received. In 2011, the median preliminary review time and total review time were 28 days and 70 days, respectively. In FY2009, the median total review time was 58 days. The total number of queries received regarding the preliminary review in FY2011 was 5,286 . The most common query was related to protocol $(n=3,429 ; 64.9 \%)$, and the second most common was related to the informed consent form $(n=1,130 ; 21.4 \%)$. Of the 3,429 queries related to protocol, the majority was related to the research methods $(n=1,542 ; 45.0 \%)$ such as the evaluation items, selection criteria, and statistical methods of analysis chosen. Our results show that the necessary application materials were not submitted in many cases. Although the total time for review was increased due to the preliminary review process, our results suggest that the preliminary reviews are meaningful and that they allow the ethics committee to conduct its review based on improved applications. However, we must continue to consider how to support clinical research and reduce the total time for review.

(Jpn J Clin Pharmacol Ther 2013; 44 (6) : 443-450)
\end{abstract}

Key words: preliminary review, ethics committee, clinical research

\section{緒 論}

臨床研究は, 社会の理解と協力を得たうえで, 疾病 の予防法, 診断法扔上び治療法の改善, 疾病の原因や 病態の理解，ならびに患者の生活の質の向上等，医療 の発展・進歩を目的として, 絶えず寒施されている. 臨床研究の実施に際しては, 科学的な観点を重視する のみではなく，倫理的な配慮も十分に検討する必要が
あり,ヘルシンキ宣言（2008 年ソウル修正）に扔いて も,「人間を対象とする医学研究に打いては, 個々の研 究被験者の福祉が他のすべての利益よりも優先されな ければならない.」(第 6 項）とされている ${ }^{1)}$. 厚生労働 省や文部科学省により臨床研究に係る省令や指針等 (各指針等) が定められており, 各指針等では臨床研究 の実施に際して, 科学的・倫理的な配慮を研究者の判 断のみに委ねるのではなく，各指針等に適合している

*1 名古屋大学医学部附属病院先端医療・臨床研究支援センター ${ }^{* 2}$ 名古屋大学大学院医学系研究科生命倫理審查委員会 別刷請求先: 清水忍 名古屋大学医学部附属病院先端医療・臨床研究支援センター $\bar{\top} 466-8560$ 名古屋市昭和区鶴舞町 65 E-mail : s-shimizu@med.nagoya-u.ac.jp

(投稿受付 2013 年 4 月 18 日，第 2 稿受付 2013 年 7 月 3 日，第 3 稿受付 2013 年 8 月 2 日，掲載決定 2013 年 8 月 14 日) 


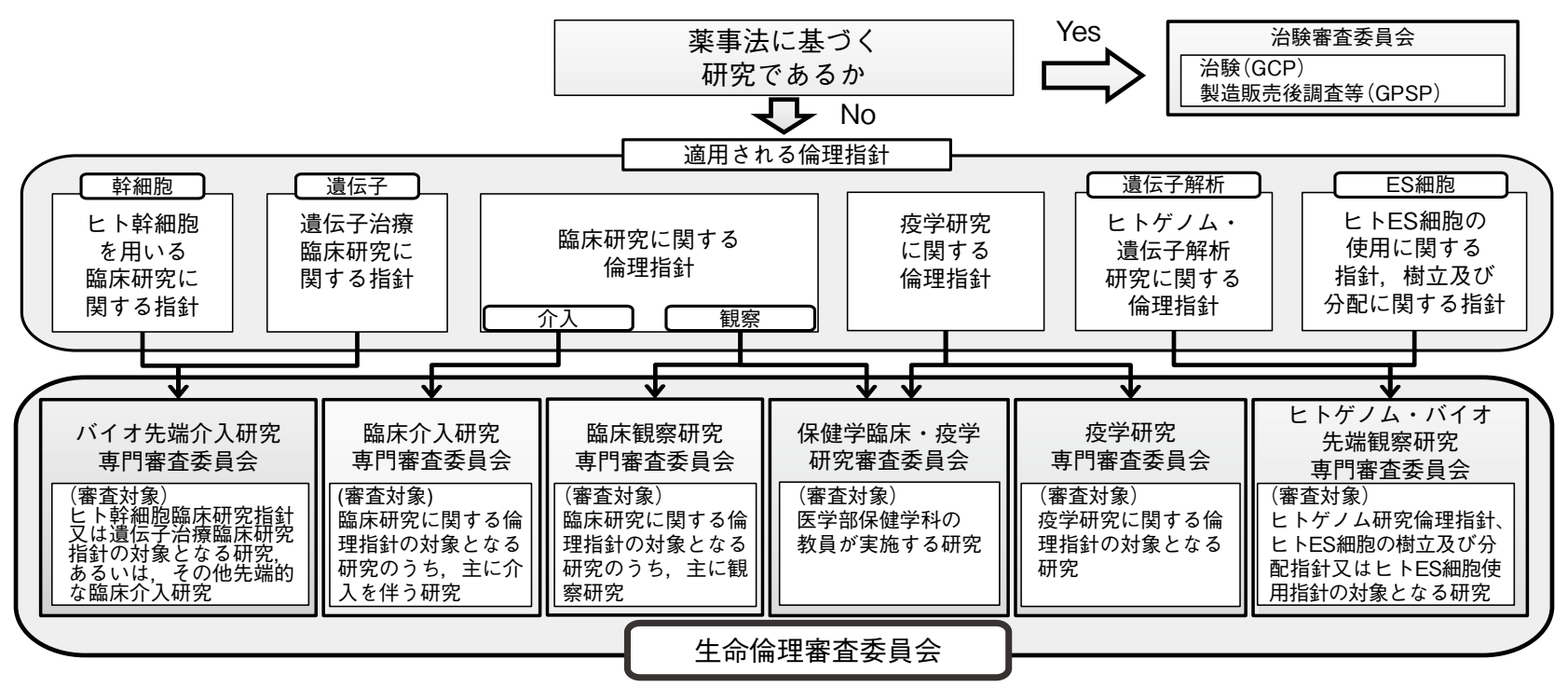

Fig. 1 名古屋大学生命倫理審査委員会の構成

か否か, 科学的・倫理的側面を考慮したうえで適切に 臨床試験を実施できるかどうかに関し，必要な事項を 研究機関の長が第三者である倫理審査委員会に審査さ せることを定めている．研究者が臨床研究を計画・実 施する際には，臨床研究の種類，どの指針を遵守して 実施するのか等を区別し，それぞれの指針に応じた取 扱いを踏まえて実施計画書，説明文書等を作成し，各 研究機関で定めた倫理審査委員会へ諮る必要がある.

名古屋大学大学院医学系研究科および医学部附属病院 (以下, 名古屋大学) では, 各指針に応じた専門審査委 員会が設置されており（Fig. 1)，それぞれの専門審査 委員会は月 1 回の頻度で開催されている ${ }^{2)}$. 申請時に 必要な資料として, 申請書, 研究概要書, 実施計画書, 説明文書 - 同意文書，利益相反自己申告書，その他必 要な資料の提出を研究者に求め, これらの資料に基づ き審査を行っている.

一方，倫理委員会関係者を対象にした聞取り調査が 実施されており, 研究者については研究の方法論や基 本的な倫理原則を熟知しておらず，実施計画書や説明 文書が書けないこと，倫理委員会については審査その ものが不十分であること，審査の効率が悪く，仕事量 が多いことが問題点の一部として挙げられている ${ }^{3)}$.

ある機関における申請者（研究者）と委員に対する調 査の結果，申請者が「研究計画書の書き方がわからな い」と感じていること，委員の意見としても「記載す べき項目が書かれていない計画書が申請されてくる」 といった状況も報告されている ${ }^{4)}$ 。また，各委員会の 責任者の回答によると,「審査案件が多すぎる」「「審査 を簡略化・迅速化した方がよい」との要望も挙がって
いる5).さらに，倫理委員会への事前準備が十分でき るほど時間的余裕を持った委員はまれで，研究計画書 を十分理解しないまま会議に臨む委員も多いと認識さ れている ${ }^{6)}$. 文部科学省・厚生労働省による「臨床研 究・治験活性化 5 か年計画 2012」においても, 臨床研 究等における倫理性および質の向上，質の高い審査を 実施することが望まれており，加えて，倫理審査委員 会事務局への専任担当者の配置も求められている7 . このような状況等も踏まえ，名古屋大学では，治験お よび名古屋大学医学部保健学科で実施する臨床研究を 除くすべての臨床研究について，平成 23 年 3 月 1 日 から，質が高く，かつ効率的な倫理審査を遂行するた めに，専門審査委員会で倫理審査を行う前に生命倫理 審査委員会事務局により週 1 回の頻度で事前審査を 行っている. 名古屋大学の生命倫理審査委員会事務局 は教員 4 名（医師 3 名 [うち研究倫理に精通する専任 の専門家 1 名, 臨床疫学者 1 名含む], 薬剤師 1 名), 薬片師 2 名（うち上級 CRC 1 名）, 事務職員 4 名から 構成されている (平成 23 年度時点)。事前審査は研究 支援の一端を担っていることから，適用関係指針への 適合性や迅速審査の妥当性に関する事項, 書類の記載 整備だけではなく，専門審査委員会において円滑に審 查ができるよう適切な研究計画内容とするため, また, 専門審査委員会で審議すべき論点を整理するため, 研 究の倫理性および科学性についても提出された資料に 基づいて確認し，提出書類を整備するよう指導を行っ ている，必要に応じ，研究者と直接研究内容について 議論を行っている，専門審査委員会では，事前審査に より確認および整備がなされた研究計画書等の書類を 

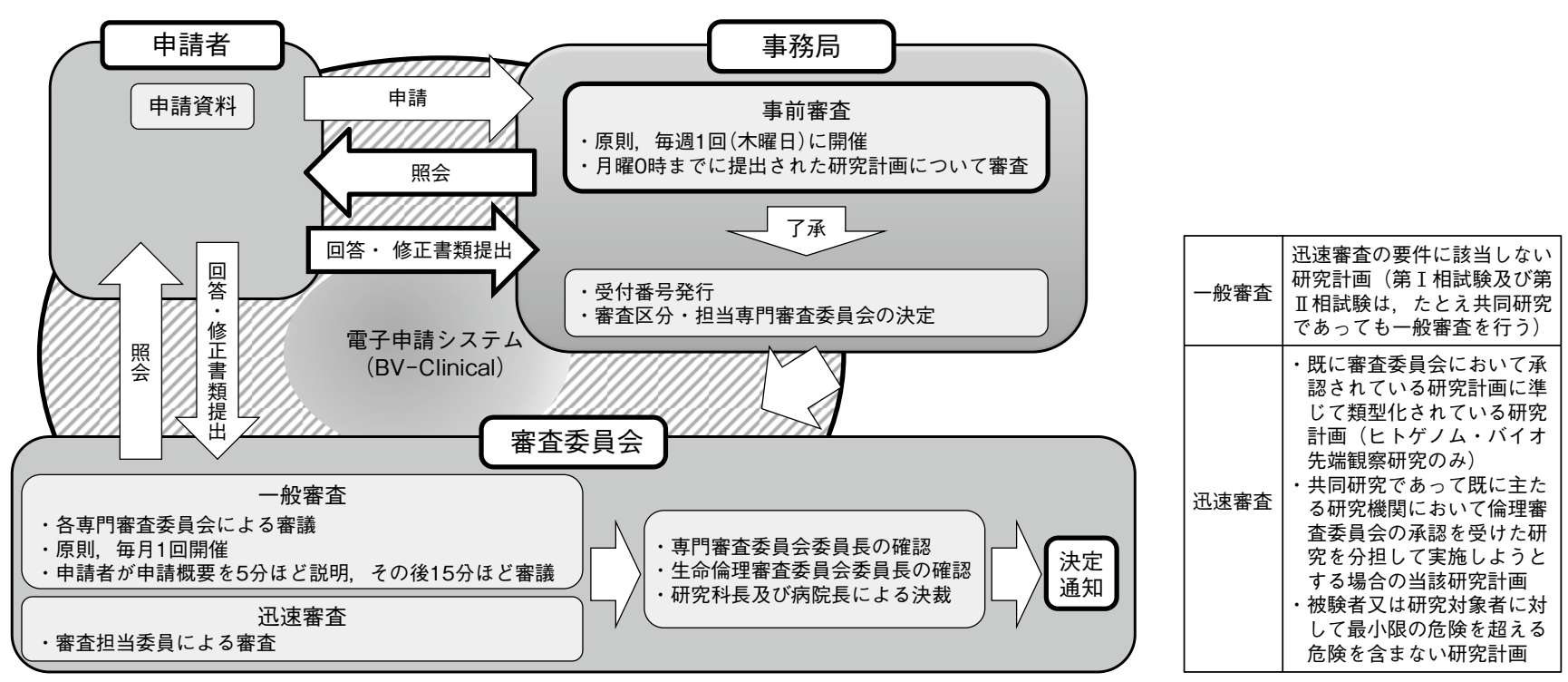

Fig. 2 審查の流れ

基に, 指針上求められている倫理性および科学性に係 る事項を中心に審査している.

現在, 事前審査は臨床試験電子審査申請システム (BV-Clinical, 株式会社ビッグバン) を介し, 事前審査 員と研究者との照会および回答により行われており， その内容は研究者, 事前審査員および生命倫理審査委 員会委員のいずれもが随時閲覧可能となっている．申 請から所属機関の長による結果通知が発出されるまで の流れを Fig. 2 に示した.

今回, 平成 23 年 3 月から導入した名古屋大学の倫 理審査における事前審査について，その意義を評価・ 検討することを目的に, 事前審査の導入が臨床研究を 開始するまでの時期に及ぼす影響，事前審査の照会内 容の調査を行った.

\section{方法}

名古屋大学において, 平成 23 年度（平成 23 年 4 月 1 日〜平成 24 年 3 月 31 日）に申請され，平成 25 年 3 月 31 日までに所属機関の長から結果通知が発出され たすべての事前審査の対象となった臨床研究につい て, 以下の事項について調査した. 各事項については, 各専門審査委員会別 (研究内容の違い), 一般審査・迅 速審査別でそれぞれ集計を行った（迅速審査の要件は Fig. 2 参照).

（1） 1 課題あたりの事前審査における照会数

(2) 事前審査の照会内容の内訳

事前審査の照会内容については, どの提出資 料に関係する照会であるのかを申請書, 実施計 画書, 説明文書・同意文書およびその他に分類
した。また，実施計画書および説明文書・同意 文書に関しては，その内訳をさらに分類した。 なお，一つの照会で二つ以上の項目に係る場合 は, 重複してカウントした.

（3）申請から事前審査で了承されるまでの期間（事 前審査期間), 事前審査で了承されてから専門 審査委員会を経て結果通知が発出されるまでの 期間（委員会審査期間）および申請から結果通 知が発出されるまでの期間（総審査期間）

（4）事前審査導入前の平成 21 年度（平成 21 年 4 月 1 日〜平成 22 年 3 月 31 日）申請分と総審査期 間の比較

\section{結 果}

平成 21 年度および平成 23 年度に申請され, 所属機関 の長から結果通知が発出された臨床研究の件数は, そ れぞれ 242 件および 259 件であり, その内訳を Table 1 に示した. なお, 平成 23 年度に申請され, 平成 25 年 3 月 31 日までにバイオ先端介入研究専門審査委員会に諮 り, 結果通知が発出された課題は認められなかった。

\section{1 課題あたりの事前審査における照会数（Table 2)}

平成 23 年度に申請された臨床研究の事前審査にお ける 1 課題あたりの照会数 (中央值 [最小值, 最大值], 以下同様) は 18 件 $[0$ 件, 85 件 $]$ であった。一般審査 の照会数は 22 件 $[0$ 件, 85 件 $]$ および迅速審査の照会 数は 12 件 $[0$ 件, 48 件 $]$ であり, 一般審査よりも迅速 審査の事前審査による照会数は少ない傾向が認められ た。また，疫学研究の照会数は 12 件 [1 件， 49 件 $]$ で 
Table 1 各年度に申請され, 所属機関の長から結果通知が発出された件数（倫理審査件数）

\begin{tabular}{|c|c|c|c|c|}
\hline & & 平成 21 年度a) & & 平成 23 年度 \\
\hline 疫学研究専門審査委員会 & 45 件 & $\begin{array}{l}\text { 一般：16 件 }(35.6 \%) \\
\text { 迅速：29 件 }(64.4 \%)\end{array}$ & 61 件 & $\begin{array}{l}\text { 一般： } 22 \text { 件 }(36.1 \%) \\
\text { 迅速： } 39 \text { 件 }(63.9 \%)\end{array}$ \\
\hline 臨床介入研究専門審査委員会 & 64 件 & $\begin{array}{c}\text { 一般： } 64 \text { 件（100\%） } \\
\text { — }^{\mathrm{b})}\end{array}$ & 83 件 & $\begin{array}{l}\text { 一般：53 件 }(63.9 \%) \\
\text { 迅速：30 件 }(36.1 \%)\end{array}$ \\
\hline 臨床観察研究専門審査委員会 & 100 件 & $\begin{array}{l}\text { 一般： } 70 \text { 件 }(70.0 \%) \\
\text { 迅速： } 30 \text { 件 }(30.0 \%)\end{array}$ & 74 件 & $\begin{array}{l}\text { 一般： } 43 \text { 件 }(58.1 \%) \\
\text { 迅速： } 31 \text { 件 }(41.9 \%)\end{array}$ \\
\hline バイオ先端介入研究専門審査委員会 & 4 件 & $\begin{array}{c}\text { 一般： } 4 \text { 件 }(100 \%) \\
-\end{array}$ & 0 件 & - \\
\hline $\begin{array}{l}\text { ヒトゲノム・バイオ先端観察研究 } \\
\text { 専門審査委員会 }\end{array}$ & 29 件 & $\begin{array}{l}\text { 一般：15 件 }(51.7 \%) \\
\text { 迅速： } 14 \text { 件 }(48.3 \%)\end{array}$ & 41 件 & $\begin{array}{l}\text { 一般：31 件 }(75.6 \%) \\
\text { 迅速：10 件 }(24.4 \%)\end{array}$ \\
\hline 合計 & 242 件 & $\begin{array}{l}\text { 一般: } 169 \text { 件 }(69.8 \%) \\
\text { 迅速： } 73 \text { 件 }(30.2 \%)\end{array}$ & 259 件 & $\begin{array}{l}\text { 一般: } 149 \text { 件 }(57.5 \%) \\
\text { 迅速 : } 110 \text { 件 }(42.5 \%)\end{array}$ \\
\hline
\end{tabular}

a ) 平成 21 年度においては，介入研究は「臨床受託研究審査委員会」で，観察研究は「臨床研究専門審査委員会」 で, 先端的な臨床介入研究は「バイオ先端臨床研究委員会」で, 遺伝子解析に係る研究は「遺伝子・ゲノム解 析研究専門委員会」でそれぞれ審議されていた。

b ）臨床受託研究審査委員会では，すべての研究を委員会審議（一般審査）としていた

Table 21 課題あたりの照会数, 事前審査期間, 委員会審査期間および総審査期間

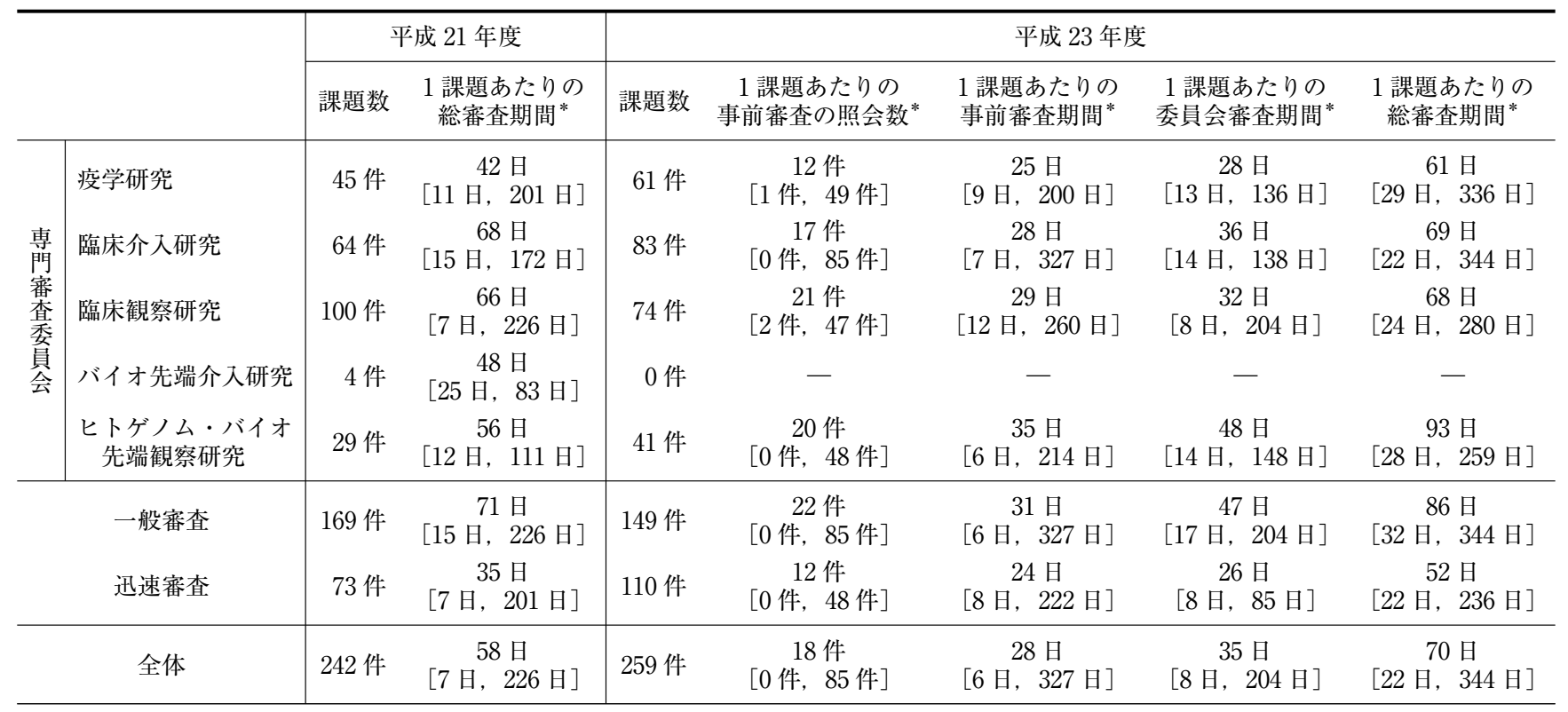

*上段 : 中央值 下段 : [最小值, 最大值]

あり，臨床介入研究の 17 件 $[0$ 件， 85 件］，臨床観察 研究の 21 件 [2 件, 47 件 $]$ およびヒトゲノム・バイオ 先端観察研究の 20 件 [0 件, 48 件 $]$ と比べ, 少ない傾 向が認められた，疫学研究以外の研究内容（臨床介入 研究, 臨床観察研究およびヒトゲノム・バイオ先端観 察研究)の違い(専門審査委員会の違い)により, 事前 審査による照会数に大きな差異は認められなかった.
2. 事前審査の照会内容の内訳 (Table 3)

平成 23 年度に申請された 259 件の臨床研究の事前 審査で, 延べ 5,286 件の照会を行った. その照会内容の 内訳は, 研究計画書に係る照会が $64.9 \%$ (照会数 3,429 件）と大半を占め, 次いで説明文書・同意文書に係る照 会が $21.4 \%$ (照会数 1,130 件)，申請書に係る照会が $9.6 \%$ (照会数 510 件)であった. この照会の傾向に研究 内容の違い (専門審査委員会の違い) や, 一般審査か, 
迅速審査かによる差異はほとんど認められなかった。

研究計画書に係る照会のうち,「研究方法に係る事 項」の照会が $45.0 \%$ (照会数 1,542 件)で大半を占めて おり，その内訳は「評価項目・検査項目・採取試料に 係る事項」,「対象被験者に係る事項（選択基準・除外 基準)」,「割付方法・解析方法に係る事項」, 「症例数設 定に係る事項」の順であり，「研究方法に係る事項」の 照会のそれぞれ $33.5 \%, 18.9 \%, 17.1 \%, 14.3 \%$ (照会 数はそれぞれ 517 件, 292 件, 263 件, 221 件) であった.

説明文書・同意文書に係る照会は，「記載整備に係る 事項」が $25.9 \%$ (照会数 293 件) で多数を占め,「研究 方法に係る事項」 $19.8 \%$ (照会数 224 件)，「被験者の 利益及び不利益に係る事項」 $18.1 \%$ (照会数 205 件) であった。

\section{3. 平成 23 年度の各審査期間（Table 2 および Fig. 3)}

平成 23 年度の事前審査期間は 28 日［6日，327日］ であり, 研究内容の違い (専門審査委員会の違い) や, 一般審査か, 迅速審査かによる差異はほとんど認めら れなかった。

また, 平成 23 年度の委員会審査期間は 35 日 [8 日, 204 日], 総審査期間は 70 日 [22 日, 344 日] であり, 迅速審査よりも一般審査の委員会審査期間および総審 査期間が延長する傾向が認められた。一方，ヒトゲノ ム・バイオ先端観察研究の委員会審査期間および総審 査期間は他の研究と比較して延長する傾向が認められ たが，その他の研究内容の違いにより委員会審査期間 および総審査期間に大きな差異は認められなかった。

\section{4. 事前審査導入前の平成 21 年度 $(2009$ 年 4 月 2010 年 3 月) 申請分と総審査期間の比較 (Table 2 および Fig. 3)}

平成 21 年度に申請され, 所属機関の長から結果通 知が発出された臨床研究 242 件の総審査期間は 58 日 [7 日, 226 日]であった. 事前審査を実施していなかっ た平成 21 年度に比べ, 平成 23 年度の総審査期間が中 央值で 12 日間の延長が認められた.

また, 平成 21 年度と平成 23 年度の総審査期間につ いて, 臨床介入研究および臨床観察研究に差異は認め られなかったが, 疫学研究およびヒトゲノム・バイオ 先端観察研究では，それぞれ平成 21 年度と比べて中 央值で 19 日拉よび 37 日の延長が認められた。一般審 查と迅速審査においても, それぞれ平成 21 年度と比 べて中央值で 15 日および 17 日の延長が認められた.

\section{考察}

名古屋大学では平成 23 年 3 月 1 日より教員等によ る内容の精查を伴う事前審査を導入し，適用関係指針 への適合性や迅速審査の妥当性に関する事項だけでは なく，専門審査委員会において円滑に審査ができるよ う適切な研究計画内容とすること，ならびに専門審査 委員会で審議すべき論点を整理することを目的に, 研 究の倫理性および科学性についても提出された資料に 基づいて確認し, 提出書類を整備するよう指導を行っ ている. 今回, 名古屋大学の生命倫理委員会事務局へ 提出された臨床研究について，その事前審査における 照会数および照会内容, ならびにこの事前審査の導入 が審査期間に及ぼす影響について調査した。

\section{1 課題あたりの事前審査における照会数について} (Table 2)

平成 23 年度に申請された臨床研究の提出資料にお いて必要事項が記載されていない等, 確認しなければ ならない事項が散見された。一般審査よりも迅速審査 の事前審査による照会数は少ない傾向が認められたこ とから，「すでに主たる研究機関において倫理審査委 員会の承認を受けた研究」は迅速審査となる要件の一 つであるため, 名古屋大学が主たる機関の臨床研究 (165 件) と他の機関が主たる機関の臨床研究 (94 件) の 1 課題あたりの照会数を追加調査した. その結果, 事前審査による照会数は名古屋大学が主たる機関の臨 床研究で 21 件 $[0$ 件, 85 件 $]$ および他の機関が主たる 機関の臨床研究で 11 件 $[0$ 件, 48 件 $]$ であり，他の施 設で審査を受けた研究は確認事項が少なかったことか ら, 迅速審査の照会数が少なくなったと考えられた. また, 疫学研究の照会数は少ない傾向が認められたが, これは迅速審査の割合が他の研究内容に比べて高いこ とに起因していると考えられた（Table 1).

\section{2. 事前審査の照会内容について（Table 3)}

研究者が作成した研究計画書および説明文書・同意 文書の記載は事前審査時に十分と判断できる資料では なく, 修正や確認が必要なものが多く認められ, 申請 資料としては不十分なものが多かった，実際，研究計 画書に係る照会の内訳から, 研究方法に関する事項が 十分に記載されていないことが明らかになった.また， 説明文書・同意文書に係る照会の内訳からも，被験者 候補に対し十分配慮された説明文書とはなっていな かった可能性が示唆された.ヘルシンキ宣言（2008 年 
Table 3 平成 23 年度の事前審査の照会内容の内訳

\begin{tabular}{|c|c|c|c|c|}
\hline & \multicolumn{4}{|c|}{ 専門審査委員会 } \\
\hline & 疫学研究 & 臨床介入研究 & 臨床観察研究 & $\begin{array}{c}\text { ヒトゲノム・バイオ } \\
\text { 先端観察研究 }\end{array}$ \\
\hline 課題数 & 61 件 & 83 件 & 74 件 & 41 件 \\
\hline 申請書 & 93 件（10.0\%） & 170 件 $(9.4 \%)$ & 171 件（10.0\%） & 76 件 $(9.0 \%)$ \\
\hline 研究計画書 & 666 件 $(71.9 \%)$ & 1,150 件 $(63.6 \%)$ & 1,077 件（63.1\%） & 536 件 $(63.5 \%)$ \\
\hline 研究方法 & 262 件 $(39.3 \%)$ & 508 件（44.2\%） & 521 件 $(48.4 \%)$ & 251 件 $(46.8 \%)$ \\
\hline $\begin{array}{l}\text { 対象被験者（選択基準・除外基準） } \\
\text { 症例数設定 } \\
\text { 評価項目・検査項目・採取試料 } \\
\text { 割付方法・解析方法 } \\
\text { その他 }\end{array}$ & $\begin{array}{l}59 \text { 件 }(22.5 \%) \\
43 \text { 件 }(16.4 \%) \\
75 \text { 件 }(28.6 \%) \\
41 \text { 件 }(15.6 \%) \\
44 \text { 件 }(16.8 \%)\end{array}$ & $\begin{array}{r}75 \text { 件 }(14.8 \%) \\
80 \text { 件 }(15.7 \%) \\
154 \text { 件 }(30.3 \%) \\
90 \text { 件 }(17.7 \%) \\
109 \text { 件 }(21.5 \%)\end{array}$ & $\begin{array}{r}94 \text { 件 }(18.0 \%) \\
68 \text { 件 }(13.1 \%) \\
210 \text { 件 }(40.3 \%) \\
91 \text { 件 }(17.5 \%) \\
58 \text { 件 }(11.1 \%)\end{array}$ & $\begin{array}{l}64 \text { 件 }(25.5 \%) \\
30 \text { 件 }(12.0 \%) \\
78 \text { 件 }(31.1 \%) \\
41 \text { 件 }(16.3 \%) \\
38 \text { 件 }(15.1 \%)\end{array}$ \\
\hline インフォームド・コンセント・個人情報保護 & 66 件 $(9.9 \%)$ & 27 件 $(2.3 \%)$ & 66 件 $(6.1 \%)$ & 54 件 (10.1\%) \\
\hline $\begin{array}{l}\text { 被験者の利益及び不利益 } \\
\end{array}$ & 18 件 $(2.7 \%)$ & 81 件 $(7.0 \%)$ & 53 件 $(4.9 \%)$ & 23 件 $(4.3 \%)$ \\
\hline 記載整備 & 215 件 $(32.3 \%)$ & 345 件 (30.0\%) & 257 件 $(23.9 \%)$ & 106 件（19.8\%） \\
\hline その他 & 105 件（15.8\%） & 189 件 $(16.4 \%)$ & 180 件 $(16.7 \%)$ & 102 件 $(19.0 \%)$ \\
\hline 説明文書・同意文書 & 123 件 $(13.3 \%)$ & 416 件 $(23.0 \%)$ & 386 件（22.6\%） & 205 件 $(24.3 \%)$ \\
\hline 研究方法 & 21 件 $(17.1 \%)$ & 80 件 $(19.2 \%)$ & 75 件 $(19.4 \%)$ & 48 件 $(23.4 \%)$ \\
\hline 被験者の利益及び不利益 & 10 件 $(8.1 \%)$ & 91 件 (21.9\%) & 69 件 (17.9\%) & 35 件 (17.1\%) \\
\hline 個人情報保護 & 7 件 $(5.7 \%)$ & 18 件 (4.3\%) & 17 件 (4.4\%) & 13 件 $(6.3 \%)$ \\
\hline 記載整備 & 16 件 $(13.0 \%)$ & 131 件（31.5\%） & 91 件 (23.6\%) & 55 件 (26.8\%) \\
\hline 情報公開用の資料 & 35 件 $(28.5 \%)$ & 0 件 $(0.0 \%)$ & 25 件 $(6.5 \%)$ & 1 件 $(0.5 \%)$ \\
\hline その他 & 34 件 (27.6\%) & 96 件 (23.1\%) & 109 件 $(28.2 \%)$ & 53 件 (25.9\%) \\
\hline その他 & 44 件（4.8\%） & 72 件（4.0\%） & 74 件 $(4.3 \%)$ & 27 件（3.2\%） \\
\hline 合計 & 926 件 $(100.0 \%)$ & 1,808 件 $(100.0 \%)$ & 1,708 件（100.0\%） & 844 件 $(100.0 \%)$ \\
\hline
\end{tabular}

FY2011 Preliminary Review Time

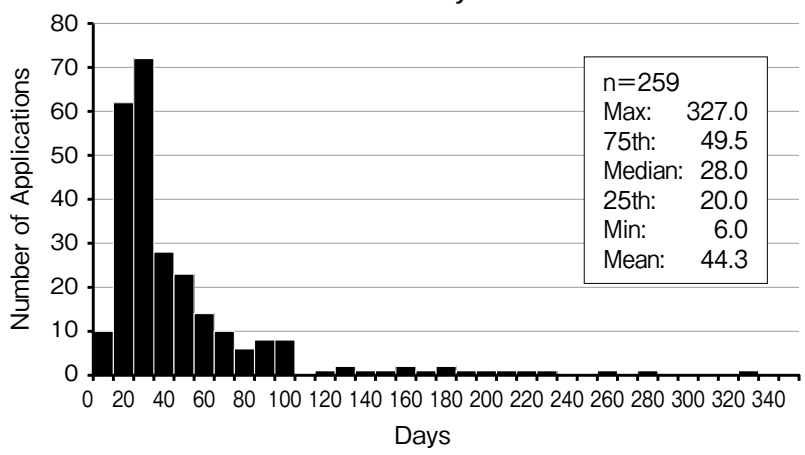

FY2011 Total Review Time

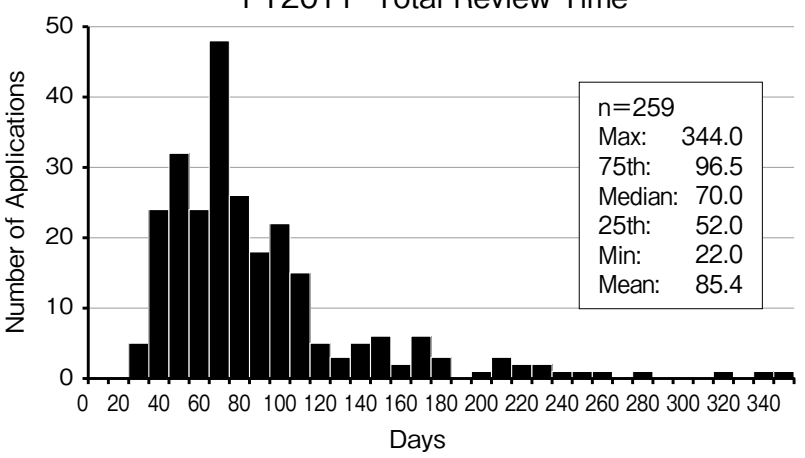

FY2011 Ethics Committee Review Time

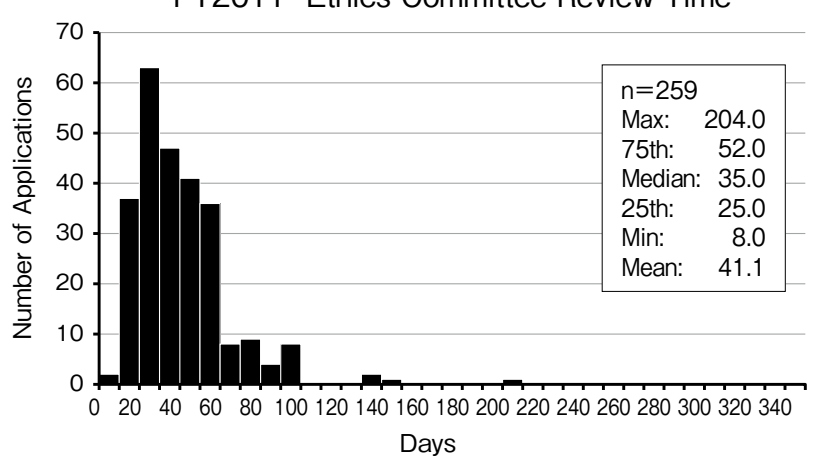

FY2009 Total Review Time

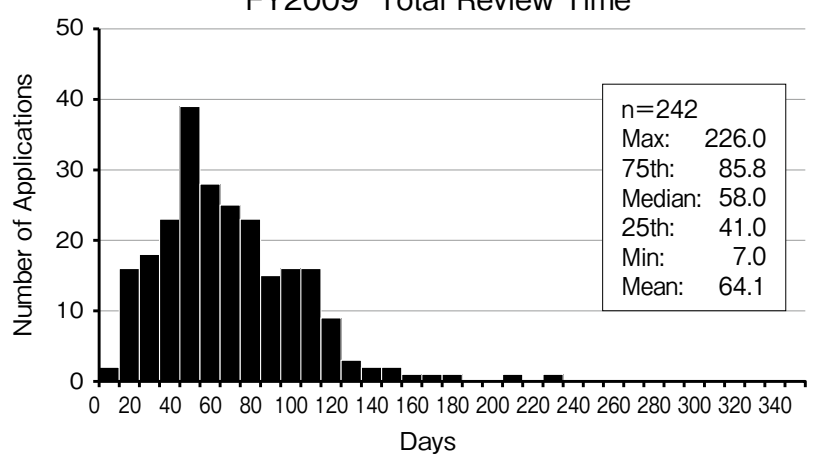

Fig. 3 Preliminary review time, ethics committee review time, and total review time in FY2011 (between April 2011 and March 2012), and total review time in FY2009 (between April 2009 and March 2010) 


\begin{tabular}{|c|c|c|}
\hline 一般審査 & 迅速審査 & 全体 \\
\hline 149 件 & 110 件 & 259 件 \\
\hline 318 件（8.8\%） & 192 件（11.6\%） & 510 件 $(9.6 \%)$ \\
\hline 2,344 件（64.6\%） & 1,085 件（65.4\%） & 3,429 件 $(64.9 \%)$ \\
\hline 1,107 件 $(47.2 \%)$ & 435 件 $(40.1 \%)$ & 1,542 件 $(45.0 \%)$ \\
\hline 225 件 $(20.3 \%)$ & 67 件 $(15.4 \%)$ & 292 件 $(18.9 \%)$ \\
\hline 157 件（14.2\%） & 64 件（14.7\%） & 221 件（14.3\%） \\
\hline 364 件（32.9\%） & 153 件（35.2\%） & 517 件（33.5\%） \\
\hline 179 件（16.2\%） & 84 件（19.3\%） & 263 件（17.1\%） \\
\hline 182 件（16.4\%） & 67 件（15.4\%） & 249 件（16.1\%） \\
\hline 139 件 (5.9\%) & 74 件（6.8\%） & 213 件 $(6.2 \%)$ \\
\hline 126 件 $(5.4 \%)$ & 49 件（4.5\%） & 175 件 $(5.1 \%)$ \\
\hline 610 件 $(26.0 \%)$ & 313 件 $(28.8 \%)$ & 923 件 $(26.9 \%)$ \\
\hline 362 件 $(15.4 \%)$ & 214 件 $(19.7 \%)$ & 576 件 $(16.8 \%)$ \\
\hline 830 件 $(22.9 \%)$ & 300 件 $(18.1 \%)$ & 1,130 件 $(21.4 \%)$ \\
\hline 175 件 $(21.1 \%)$ & 49 件 $(16.3 \%)$ & 224 件 $(19.8 \%)$ \\
\hline 172 件 $(20.7 \%)$ & 33 件 (11.0\%) & 205 件 $(18.1 \%)$ \\
\hline 41 件 (4.9\%) & 14 件 (4.7\%) & 55 件 (4.9\%) \\
\hline 226 件 $(27.2 \%)$ & 67 件 $(22.3 \%)$ & 293 件 $(25.9 \%)$ \\
\hline 14 件（1.7\%） & 47 件 $(15.7 \%)$ & 61 件 $(5.4 \%)$ \\
\hline 202 件 $(24.3 \%)$ & 90 件 $(30.0 \%)$ & 292 件 $(25.8 \%)$ \\
\hline 135 件（3.7\%） & 82 件 $(4.9 \%)$ & 217 件 $(4.1 \%)$ \\
\hline 3,627 件（100.0\%） & 1,659 件 $(100.0 \%)$ & 5,286 件 $(100.0 \%)$ \\
\hline
\end{tabular}

照会数 (割合)

ソウル修正）においては,「人間を対象とする各研究の 計画と作業内容は，研究計画書の中に明示されていな ければならない.」(第 14 項)とされ，また, 被験者候補に 対し，研究に係るすべての側面について十分に説明す る必要がある旨（第 24 項）が記載されており ${ }^{1)}$ ，また， 臨床試験はその目的を達成するために，適切な科学的 原則に従ってデザインされ, 実施され, 解析されるべき である旨が「臨床試験の一般指針」に記載されてい る ${ }^{8)}$. しかし, 倫理委員会関係者, あるいは委員や申請者 (研究者) を対象にした調査において, 研究者について は研究の方法論や基本的な倫理原則を熟知しておら ず，実施計画書や説明文書が書けないことが問題とし て挙げられているが ${ }^{3,4)}$ ，これらの報告書で提言されて からも同様の問題が継続していることが示唆された.

\section{3. 事前審査期間, 委員会審査期間および総審査期間につ}

いて（Table 2 および Fig. 3)

総審査期間について,「第 44 回医学系大学倫理委員 会連絡会議一倫理委員会に関する諸問題一」のアン ケート集計結果において, 臨床研究の承認までの平均
日数は中央值で 30 日 $[7$ 日，77日］であったことを勘 案すると ${ }^{9)}$, 他の医療機関に比べ平成 23 年度の総審査 期間は長いことが示された。 そのため, 総審査期間を 短縮する方策を検討する必要があると考える.

一方，迅速審査よりも一般審査の委員会審査期間お よび総審査期間が延長する傾向が認められたことにつ いては，迅速審査は事前審査終了後，専門審査委員の 中から 1 名の担当委員が選出され審査が随時実施され た後，委員長および所属機関の長の判断が仰がれてい るが，一般審査は毎月決められた時期に定期的に開催 されていることに起因したものと考える．また，ヒト ゲノム・バイオ先端観察研究の委員会審査期間および 総審査期間は他の研究と比較して延長する傾向が認め られたが, 平成 23 年度のヒトゲノム・バイオ先端観察 研究では一般審査の割合が他の研究に比べても高かっ たことが一因として考えられた（Table 1).

なお，事前審査期間や総審査期間と照会数の関連性 を検討したところ，事前審査における 1 課題あたりの 照会数と事前審査期間や総審査期間との間に高い相関 は認められなかったことから（1 課題あたりの照会数 と事前審查期間の相関係数 $0.5597,1$ 課題あたりの照 会数と総審査期間の相関係数 0.5430), 事前審査期間 や総審査期間が長期化している課題は事前審査による 照会数のみによるものではないことが示唆された.

\section{4. 事前審査導入前後の総審査期間の比較について}

（Table 2 および Fig. 3)

平成 21 年度に比べ，平成 23 年度の総審査期間の延 長が認められたが，これは事前審査導入による影響で あると考えられた. Table 3 からも申請時に研究計画 書や説明文書等の適切な申請資料が構成されていな かった可能性が示唆されたが，より適切な研究計画書 等の申請資料に再構成され，その資料を基に専門審査 委員会での審議が可能となることからこの期間の延長 は必要な期間であったと考えられる。平成 21 年度に は名古屋大学でこのような事前に申請資料を確認する システムはなかったため，事前審査導入前には申請資 料の不備の修正も含めて専門審査委員会において指導 が行われていた，専門審査委員会の関与は，事前審査 導入前 (平成 21 年度) は申請時からであり, 事前審査導 入後 (平成 23 年度) は事前審査後からになるため, 平成 21 年度の総審査期間を委員会審査期間とほぼ同義で あると仮定し，平成 23 年度の委員会審査期間を比較 したところ, 中央值で 23 日の差異が認められた。この ことは，事前審査により専門審査委員会の審査期間が 
短縮していると評価することもできると考えられる.

なお, 平成 23 年度の疫学研究およびヒトゲノム・バ イオ先端観察研究の総審査期間は, 平成 21 年度と比 べて延長する傾向が認められた，疫学研究は平成 21 年度も平成 23 年度のいずれも迅速審査の割合が高い ため, 平成 23 年度に導入した事前審査の影響を受け, また, ヒトゲノム・バイオ先端観察研究は平成 21 年度 と比べ, 平成 23 年度の一般審査の割合が高くなった ことが一因と考える.

\section{5. まとめ}

今回の調查における状況，ならびに，「臨床研究・治 験活性化 5 か年計画 2012$\rfloor^{7}$ ) およ゙委員や申請者（研 究者）に対する調査 ${ }^{4}$ で医師等の人材育成・教育およ び人材確保が検討課題として挙げられていることも勘 案すると, 継続して臨床試験の実施に関する教育を行 う等, 臨床研究実施体制の改善のための対策が重要で あると考えられた，その改善策の一つとして，名古屋 大学では臨床試験に関する教育を推進するため, 平成 24 年度から「生物統計セミナー」を, 平成 25 年度から 「臨床研究セミナー」をそれぞれ毎月開催することと し，臨床試験を担う医師および臨床試験を支援する者 の育成・教育を継続して実施する方針としている。こ れらのセミナーは名古屋大学のみに限定することな く, 中部地区の 7 大学と 1 センターが協同して設立し た中部先端医療開発円環コンソーシアムに参加する機 関（愛知医科大学，金沢大学，岐阜大学，名古屋市立 大学, 名古屋大学, 藤田保健衛生大学, 三重大学, 国 立長寿医療研究センター）にも周知されることになっ ている。このような研究者に対する教育を推進するこ とで提出書類の精度を向上させることが可能となると 考える。 また，名古屋大学の先端医療・臨床研究支援 センターでは, 平成 25 年 4 月より臨床研究相談空口 も設置し, 質の高い研究を実施するための支援体制を 構築している。 これらの対応とともに, 併せて研究計 画書や説明文書等の様式の工夫等も継続して検討し, より効率的かつ適切に事前審査および倫理審査を実施 する必要があると考える.

東京大学医科学研究所や米国のいくつかの施設にお いては, 支援内容はさまざまであるものの,「研究倫理 コンサルテーション」として研究者の支援を行ってい るため ${ }^{10)}$ ，これらの支援内容や支援方法も参考にしつ つ, 今後, 総審査期間を短縮する方法や研究の質を向上 させる方法を継続して検討し，より効率的かつ適切に 事前審査および倫理審査を実施することで，質の高い
臨床研究の実施を推進していくことが重要と考える.

\section{結＼cjkstart論}

今回名古屋大学で平成 23 年 3 月から導入した内容 の精査を伴う事前審査について調査を行った.

平成 23 年度の 1 年間で延べ 5,000 件以上の照会が 行われており，申請時に提出された研究計画書等の各 書類に不備がある研究が多く認められた。事前審査の 指摘により必要な事項が記載された研究計画書や説明 文書等に改訂され，委員会審査期間としてはより短縮 しており，事前審査の導入には一定の意義があると考 えられた. 申請時からの総審査期間は延長していたが, この期間でより適切な申請資料が構成できたことを勘案 すると,この修正にかかる期間は現状では必要な期間で あると考えられた．事前審査員の負荷は相当なものであ るため, その負荷を軽減する方策や総審査期間を短縮す る方策も並行して検討することも重要であると考える。

\section{Conflict of Interest}

著者全員に扔いて, 本研究論文の発表に関連して, 開示す べき COI 関係にある企業等はない.

\section{文献}

1）日本医師会 (訳)。ヘルシンキ宣言 人間を対象とする医学研究の 倫理的原則（ソウル修正）2008. 〔http://dl.med.or.jp/dl-med/ wma/helsinki2008j.pdf (accessed 2013-4-18)]

2）飯島祥彦.よくわかる医学研究倫理指針. 臨床神経. $2011 ; 51$ : 830-3.

3）佐藤恵子、被験者保護を中心とした研究マネジメントシステム の提案. 厚生労働科学研究研究費補助金 ヒトゲノム・再生医療 等研究事業 遺伝子解析研究・再生医療等の先端医療分野に扔け る研究の審查及び監視機関の機能と役割に関する研究 平成 15 年度 総括·分担研究報告書 平成 16 (2004) 年 4 月. 2004; 19-24.

4）鈴木美香，佐藤恵子．研究倫理審査委員会の現状と改善策の提 案 一ある施設に扔ける臨床研究を対象とした平成 18 年度の審 查過程の調查及び委員, 申請者の意識調查より一. 臨床薬理. $2010 ; 41(3): 113-24$.

5）原昌平, 増田弘治. 日本の特定機能病院に打ける倫理審査委員会 の現状一読売新聞によるアンケート結果の紹介と, 倫理審査の 改善に向けた考察一。臨床評価. $2007 ； 35(2) ： 375-408$.

6）笹栗俊之. 日本の研究倫理審査一どこで, 何について, 何をべー スに判断するか一. 臨床薬理. $2013 ； 44(2) ： 145-8$.

7）文部科学省高等教育局長 - 研究振興局長, 厚生労働省医政局長. 「臨床研究・治験活性化 5 か年計画 2012」について. 23 文科高第 1304 号, 医政発 0330 第 33 号. 平成 24 年 3 月 30 日.

8）厚生省医薬安全局審查管理課長. 臨床試験の一般指針. 医薬審第 380 号. 平成 10 年 4 月 21 日.

9）第 44 回医学系大学倫理委員会連絡会議一倫理委員会に関する諸 問題一アンケート集計結果. 第 44 回医学系大学倫理委員会連 絡会議プログラム・抄録集添付資料.

10）神里彩子, 武藤香織.「研究倫理コンサルテーション」の現状と 今後の課題一東京大学医科学研究所研究倫理支援室の経験よ り一. 生命倫理. $2010 ； 20$ (1)：183-93. 